\title{
Keeping your audience: Presenting a visitor engagement scale
}

\author{
Tourism Management
}

Babak Taheri, Heriot-Watt University, Edinburgh (UK), Aliakbar Jafari, University of

Strathclyde, Glasgow (UK) \& Kevin O’Gorman, Heriot-Watt University, Edinburgh (UK)

\begin{abstract}
Understanding visitors' level of engagement with tourist attractions is vital for successful heritage management and marketing. This paper develops a scale to measure visitors' level of engagement in tourist attractions. It also establishes a relationship between the drivers of engagement and level of engagement using Partial Least Square, whereby both formative and reflective scales are included. The structural model is tested with a sample of 625 visitors at Kelvingrove Museum in Glasgow, UK. The empirical validation of the conceptual model supports the research hypotheses. Whilst prior knowledge, recreational motivation and omnivore-univore cultural capital positively affect visitors level of engagement, there is no significant relationship between reflective motivation and level of engagement. These findings contribute to a better understanding of visitor engagement in tourist attractions. A series of managerial implications are also proposed.
\end{abstract}

\section{Graphical Abstract}

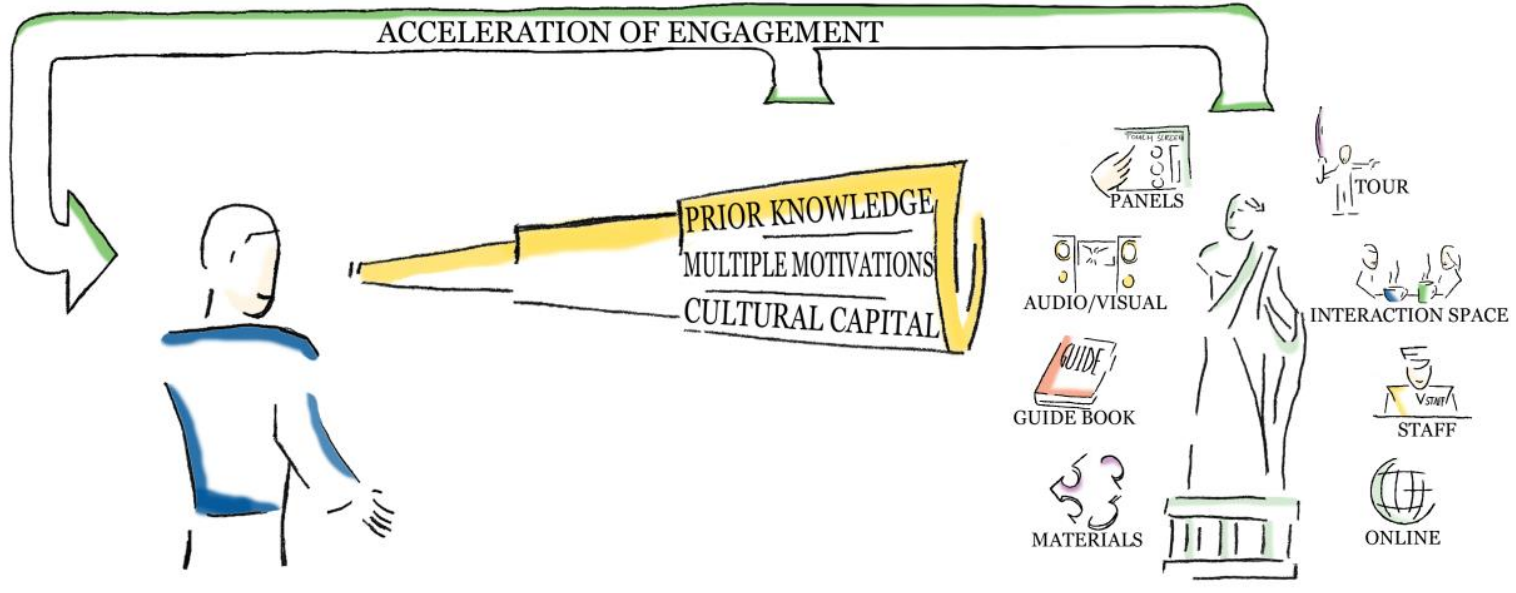

Keywords: Visitor engagement, Scale development, PLS, Heritage

\section{Highlights:}

- Develops a new visitor engagement scale

- Establishes a relationship between the drivers and level of engagement

- Tests a structural model using formative and reflective scales

- Provides a tool for managers to assess engagement systematically 


\section{Introduction}

Engagement is an established topic within the tourism literature. Better engagement with an attraction's context and contents optimizes the overall visitor experience and also enhances its value proposition. Greater understanding of engagement can inform the predictability of the visitor's behavior (Sheng \& Chen, 2012; Black, 2012). Engagement in this paper is perceived as involvement with and commitment to a consumption experience (Brodie, Hollebeek, Juric', \& Ilic', 2011). Previous studies (Serrell, 1998; Falk \& Storksdieck, 2005) have used observation techniques and experiments to understand visitors' engagement. However, such studies have focused mainly on the length of time visitors spend in the tourism attractions rather than their involvement with and commitment to the experience. Moreover, these techniques do not fully capture visitors' level of engagement.

Using museums as a research context, our first objective is to investigate the relationship between the drivers of engagement and level of engagement to develop a scale to measure visitors' level of engagement; to our knowledge, such a scale does not exist in the extant literature. This instrument can add value to tourism research and management practice as it can be used to predict tourists' behavior in terms of their engagement. Such predictability relates to the key drivers of engagement (i.e., prior knowledge, intrinsic motivations and cultural capital) and better understanding of these drivers can inform better management of engagement. Previous research has called for empirical work to document the relationship between visitors' prior knowledge (Black, 2005), multiple motivations (Prentice, 2004b), and cultural capital (Kim, Cheng, \& O'Leary, 2007) and their level of engagement. Our second objective relates to measurement issues in general. We echo Žabkar, Brenčič and Dmitrovič's (2010) call for advancing scale development and measurement in tourism studies as a majority of scales in business research use reflective scales (i.e., based on classical test theory where the measured indicators are assumed to be caused by the construct) instead of formative scales (i.e., indicators cause changes in the construct) (see also Diamantopoulos \& Winklhofer, 2001; Wiedmann, Hennigs, Schmidt \& Wuestefeld, 2011). Building upon this argument, we test level of engagement and prior knowledge formatively and multiple motivations reflectively.

The contributions of the study are threefold: 1) the development of a new scale, with a high applied value to managers and researchers, to measure level of engagement; 2) contribution to the extant literature by establishing a relationship between the 'drivers' and 'level' of engagement; 3) from a methodological perspective, it tests a structural model including formative and reflective scales.

\section{Literature review}

\subsection{Engagement}

Engagement is context and discipline bound and defined in different ways (Brodie, Ilic, Juric, \& Hollebeek, 2013; Higgins \& Scholer, 2009; Mollen \& Wilson, 2010): attachment (Ball \&Tasaki, 1992), commitment (Mollen \& Wilson, 2010), devotion (Pimentel \& Reynolds, 2004), and emotional connection (Marci, 2006). It also features in the social science including sociology (civic engagement), psychology (task engagement), marketing (customer engagement), and organizational behavior (employee engagement) (Brodie et al., 2011). Brodie et al. (2013) argue that engagement goes beyond involvement to embrace a proactive consumer relationship with specific engagement object. Wang (2006) highlights that measuring the time consumers spend with service offerings is pivotal to understanding 
their engagement. For the purposes of this study engagement is conceptualized as: a state of being involved with and committed to a specific market offering (Higgins \& Scholer 2009; Abdul-Ghani, Hyde and Marshall 2011)

In marketing, engagement is a two-way interaction between subjects e.g., consumers, tourists and objects e.g., brands, tourist attractions (Hollebeek, 2010). As a multidimensional concept, engagement includes cognitive, emotional and/or behavioral elements (Hollebeek, 2010; Brodie et al., 2011). This varies across engagement actors (i.e., subjects and objects) and/or contexts (i.e., consumption situations) (Brodie et al., 2011). For example, the relationship between the consumer and service provider is built upon the engagement of both parties in a constant process of exchange. That is, the service provider attempts to deliver the experience the consumer seeks (Mollen \& Wilson, 2010; Hollebeek, 2012).

Not all consumers enjoy the same level of engagement, and engaged consumers derive more benefits from their consumption experience (Brodie et al., 2011; Higgins \& Scholer, 2009). New and repeat purchasers have different levels of familiarity with a specific service offering and their level of engagement may vary (Mollen \& Wilson, 2010; Hollebeek, 2012). Similarly, consumers' level of motivations and knowledge influence their engagement with a service offering (Hollebeek, 2012; Brodie et al., 2013). Motivated consumers are normally more committed to and involved with service offerings (van Doorn et al., 2010). Also those with higher knowledge of the context demonstrate higher levels of engagement with their experience (Holt, 1998). Whilst such relationships between engagement and its influential factors have been extensively studied in the literature of marketing, they have received little attention in the realm of tourism research (e.g., Falk, Ballantyne, Packer, \& Benckendorff, 2012; Ballantyne, Packer \& Falk, 2011); our study addresses this gap in the literature.

\subsection{Drivers of engagement in tourism}

The literature identifies three drivers of engagement: Prior knowledge, multiple motivations and cultural capital, these are summarized in Table 1. Prior knowledge influences tourist behavior and decision making, in particular familiarity, awareness and specific knowledge of target attractions determine preference for particular destinations (Baloglu, 2001; Gursoy \& McCleary, 2004; Ho, Lin, \& Chen, 2012; Prentice, 2004a). Prior knowledge is a multidimensional construct comprising of: familiarity with the attraction (awareness of the product through acquired information) (Park \& Lessig, 1981), expertise (knowledge and skill) (Mitchell \& Dacin, 1996), and past experience (endurance of previous visits) (Moore \& Lehmann, 1980). However, as Kerstetter and Cho (2004) stress, previous studies have not examined prior knowledge in its entirety. That is, familiarity, expertise, and past experience which essentially form the construct of prior knowledge - have been studied in isolation. Therefore, we argue that prior knowledge should be conceptualized as an 'aggregated' construct simply because dropping any dimension(s) of the construct alters its conceptual meaning.

Demographic, socio-economic characteristics and multiple motivations affect consumption behavior, however, only multiple motivations are directly related to intention because they are not situation dependent (Park \& Yoon, 2009). Comprehending motivation is key to understanding tourists' decisions and behaviors (Iso-Ahola, 1982; Prentice, 2004b; Park \& Yoon, 2009; Kolar \& Zabkar, 2010). The prevalent dichotomous view of motivation distinguishes between push (i.e., motivations that drive individuals' interest in tourism) and pull (i.e., attractiveness of a destination that draws individuals to a specific place) factors 
(Baloglu \& Uysal 1996). Push factors emerge from intrinsic (behavior for its own sake) and/or extrinsic (behavior for external rewards) grounds (Iso-Ahola, 1982). There is need for empirical investigation to better understand the impact of multiple motivation benefits on level of engagement (Stebbins, 2009; Black, 2005; Falk, Dierking \& Adams, 2011; Ballantyne et al., 2011).

Table 1 Engagement Drivers

\begin{tabular}{lll}
\hline Driver & Content & Authors \\
\hline $\begin{array}{l}\text { Prior } \\
\text { Knowledge }\end{array}$ & $\begin{array}{l}\text { Familiarity, expertise including } \\
\text { knowledge and skill and past experience } \\
\text { of the site }\end{array}$ & $\begin{array}{l}\text { Baloglu, 2001; Gursoy \& McCleary, } \\
\text { 2004; Ho, Lin, \& Chen, 2012; Kerstetter } \\
\text { and Cho 2004; Mitchell \& Dacin, 1996; } \\
\text { Moore \& Lehmann, 1980; Park \& Lessig, } \\
\text { 1981; Prentice, 2004a }\end{array}$ \\
$\begin{array}{lll}\text { Multiple } \\
\text { Motivations }\end{array}$ & $\begin{array}{l}\text { Self-expression, self-actualisation, self- } \\
\text { image, group attraction, enjoyment, } \\
\text { satisfaction, recreation, and person } \\
\text { enrichment. }\end{array}$ & $\begin{array}{l}\text { Baloglu \& Uysal 1996; Iso-Ahola, 1982; } \\
\text { Prentice, 2004b; Park \& Yoon, 2009; } \\
\text { Kolar \& Zabkar, 2010 Stebbins, 2009; } \\
\text { Black, 2009; Falk et al., 2011; Ballantyne } \\
\text { et al., 2011 }\end{array}$ \\
& $\begin{array}{l}\text { Social origins and the accumulation of } \\
\text { Cultural } \\
\text { Capital }\end{array}$ & $\begin{array}{l}\text { Bourdieu 1984; Holt, 1998; Peterson, } \\
\text { 2005; Stringfellow et al. 2013 }\end{array}$ \\
\hline
\end{tabular}

Finally cultural capital (Bourdieu 1984) has been used to analyze cultural consumers' preferences and practices (Holt, 1998; Peterson, 2005; Stringfellow, Maclaren, Maclean, \& O'Gorman, 2013). Cultural capital refers to the accumulation of cultural practices, tastes, educational capital and social origins which affect individuals' ability to consume cultural products. Cultural capital is explained in three different ways: 1) 'homology' states that people in higher social strata (with higher cultural capital) prefer to consume elite culture and individuals in lower social strata prefer to consume mass or popular culture; 2) 'individualism' explains that in contemporary society, individuals are no longer grounded in any solid socio-economic class; rather, they are free-floating individuals who surf multiple identities and lifestyles in search of self-realization 3) with a focus on the frequency of consumption, the 'omnivore-univore' view describes omnivores as those who are interested in a variety of tastes and univores as those who have limited tastes (Peterson, 2005; Chan and Goldthorpe, 2007). The omnivore-univore perspective also differentiates between 'active' and 'inactive' individuals. The former are those who engage more frequently in a broader range of cultural activities and the latter are those who engage less frequently in fewer cultural activities. This study uses Peterson's (2005) 'omnivore-univore' view.

\subsection{Engagement and museums}

Engagement with(in) the museum optimizes visitors' consumption experience (Edmonds, Muller, \& Connell, 2006; Welsh, 2005) Traditionally, museums measure their success on the average time visitors spend, however, time spent does not necessarily mean engagement. Visitors may, for example, spend time in the coffee shop (Falk \& Storksdieck, 2005). For visitor retention, museums need to engage in innovative presentation and interpretation techniques; this is in keeping with both the educational and recreational roles of modern museums (Welsh, 2005).

Three attributes are important for engagement: 1) Attractors ("those things that encourage the audience to take note of the system in the first place"); 2) Sustainers ("those attributes that keep the audience engaged during an initial encounter"); and 3) Relaters 
("aspects that help a continuing relationship to grow so that the audience returns to the work on future occasions") (Edmonds et al., 2006, p.307). Previous studies focused on how visitors influence their engagement with the museum (Black, 2009; French \& Runyard, 2011). Moscardo (1996) distinguishes between 'mindful' visitors who experience greater learning and understanding as well as higher levels of satisfaction than 'mindless' ones. Pattakos (2010) contends that tourists' levels of engagement rest upon a continuum with those at the highest level being most committed to their experience. Finally, Edmonds et al. (2006) and Black (2005) demonstrate how active and passive visitors may or may not engage with exhibits where technological means (e.g., light and sound effects, computer programs, and sensors) are facilitators. This highlights that levels of engagement vary with higher levels of engagement bringing superior rewards for cultural consumers.

Prior knowledge of the museum influences visitors' choice, their activities, and also the rewards they seek in their visits. In order to gain a more profound (e.g., more enjoyable, enriching, and informative) consumption experience, visitors can enhance their knowledge of the museum by gathering information from various sources such as family and friends, visitor information, mass media and websites (Falk \& Dierking, 1992; Falk \& Storksdieck, 2005; Sheng \& Chen, 2012). In the context of arts consumption, Caru and Cova (2005) confirm that individuals' prior knowledge and experience contribute to their appreciation. Similarly, Black (2005) shows that visitors with higher levels of museum experience and knowledge about the content of an exhibition happen to experience a higher level of engagement during their visit.

Museums can optimize the consumption experience by leveraging visitors' cultural capital (particular knowledge) and enhancing engagement (Black, 2005; Siu, Zhang, Dong, \& Kwan, 2013). However, there is little evidence of a specific link between cultural capital engagement levels. Falk et al., (2011) note the relationship between cultural capital and engagement requires scrutiny as an integral part of the visitor agenda, furthermore, cultural capital could be a rich repository from which visitors draw meaning (Black, 2005; Kim, Cheng \& O'Leary, 2007; Tampubolon,2010).

Museum studies have associated visitor interests with a series of cognitive (e.g., learning), affective (e.g., nostalgia), reflective (e.g., identity projects) and recreational (e.g., hedonism) motivations (Prentice, 2001; Slater, 2007; Falk \& Storksdieck, 2010; Falk et al., 2011). Such studies have advanced understanding of reasons for visiting; yet, they have not sufficiently explained how these motivations may influence individuals' engagement during their experience. Stebbins' (2009) analysis of 'serious leisure' helps to address this gap; during a serious leisure activity, individuals with higher levels of intrinsic motivations experience feelings of productivity and a sense of progress which in turn result in higher levels of engagement. Prentice (2004b) views Stebbins' analysis of 'serious leisure' valuable to the conceptualization of tourists' motivations and calls for empirical investigation of such motivations. Some consumers are motivated by attaining stages of achievement, the acquisition of particular knowledge and the desire for intrinsic rewards (Prentice 2004b). Furthermore, Barbieri and Sotomayor (2013) argue that the multiple motivation benefits of serious leisure can help to predict involvement and commitment. Figure 1 shows, from the literature, the three main drivers of engagement: prior knowledge, multiple motivations, and cultural capital which influence the level of engagement. 


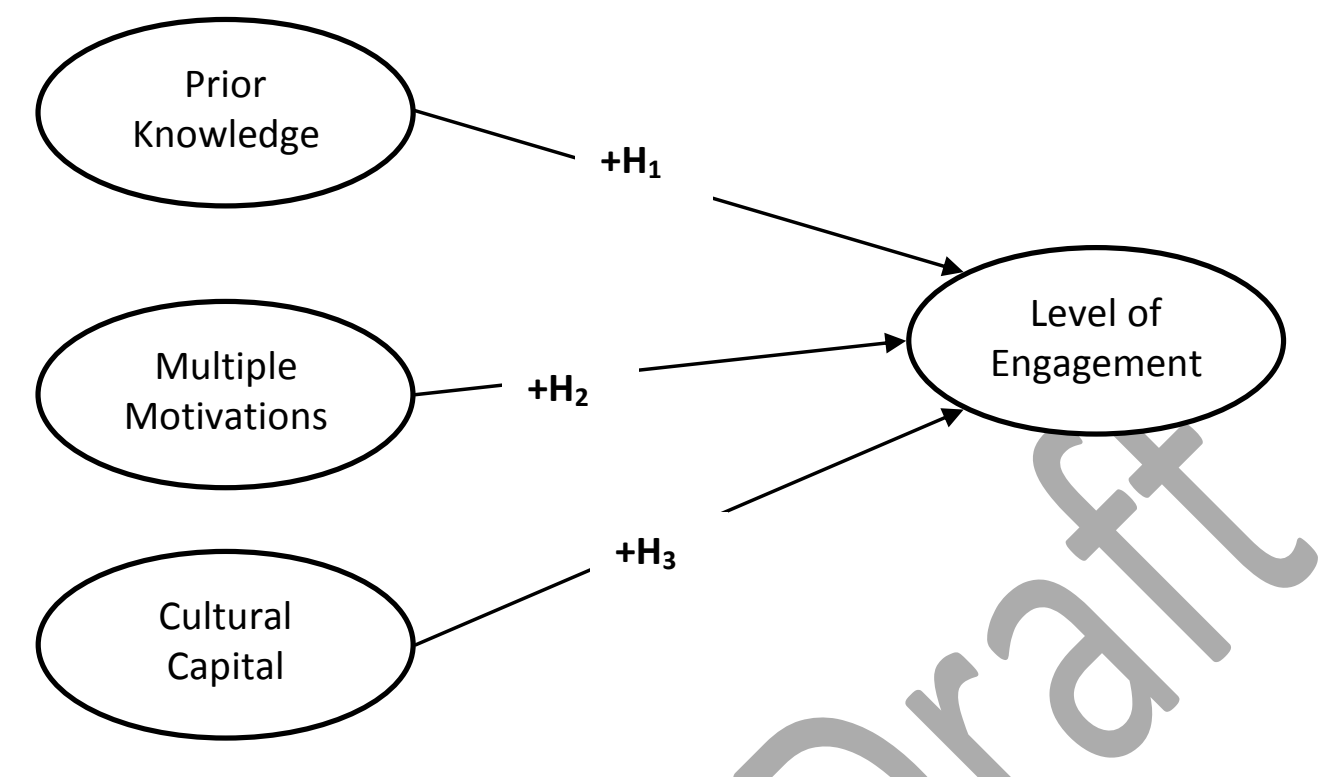

Figure 1: Initial model and hypotheses

\section{Research design}

We adopted a mixed-method approach where the results from one study develop the other (Alexander, MacLaren, O'Gorman, \& Taheri, 2012), thus increasing the validity of scales whilst examining results by capitalizing on inbuilt method strengths. Therefore, a qualitative study was used to develop the level of engagement scale followed by a Partial Least Squares (PLS) model to examine the impacts of drivers of engagement.

\subsection{Stage 1: Scale development}

Engagement was measured as a formative scale comprising the full range of indicators that could represent it. Following Diamantopoulos \& Winklhofer (2001), we used a four-step procedure for constructing indexes based on formative indicators: content specification, indicator specification, indicator collinearity, and external validity. The indicators were drawn from a review of the relevant literature in order to capture the scope of engagement (i.e. scope of the scale). To determine whether the statements could fully capture the engagement scale's domain of content, we employed exploratory interviews with museum visitors. Through convenience sampling, data were collected in Kelvingrove Art Gallery and Museum in Glasgow. We chose this venue for two reasons: 1) as opposed to specifically-themed museums (e.g., science museums), Kelvingrove is a general site which offers a plethora of exhibits/artifacts and attracts visitors with diverse tastes and backgrounds. Therefore, the diversity of cultural capital would be better captured; 2) the museum has a broad range of interactive tools (e.g., installed screens, puzzles, and audio-video equipment) which facilitate engagement.

To check the appropriateness of the listed items, some respondents were interviewed twice. Interviewees' suggestions helped specify indicators capturing the formative scale (i.e., 
the entire scope of engagement) and later on some items were made redundant; other items were refined. The interviewees constantly agreed that these listed items accurately defined level of engagement; that is, indicator specification (Diamantopoulos \& Winklhofer, 2001; Rossiter, 2002). Apart from our post-interview member check with our participants (to ensure that our interpretation was reflective of their views), we also asked four experts from amongst our colleagues to read some of our transcripts. This way we tried to enhance the content validity and credibility of our interpretations (Slater \& Armstrong, 2010).

\section{Table 2: Engagement formative indicators}

\section{Statements}

Eng 1. Using (interactive) panels

Eng 2. Using guided tour

Eng 3. Using videos and audios

Eng 4. Using social interaction space

Eng 5. Using my own guide book and literature

Eng 6. Seeking help from staff

Eng 7. Playing with materials such as toys, jigsaw puzzle and quizzes

Eng 8. Using the on-site online facilities

In our analysis, we followed a thematic approach (Boyatzis, 1998) to search for similarities, differences and ultimately patterns and relationships in the data. The engagement scale is an aggregate of 8 items which were used as statements (Table 2) in the questionnaire. The engagement question included a seven point scale ranging from $1=$ not at all to $7=\mathrm{a}$ lot. The instruction question was: "Please circle the number that best represents how much you used each of the following items during today's visit". The scale was further tested for indicator collinearity and external validity in the result section.

\subsection{Stage 2: Quantitative study}

A questionnaire survey was executed at Kelvingrove Museum and Art Gallery using quota sampling, the basis for the quota was Morris Hargreaves McIntyre report (2009). Local and non-local respondents were both first time and repeat visitors who were intercepted on leaving the museum at the end of their visit. Whilst some of them were alone, a majority (almost 90\%) were with companions (see Table 3). Previous research (e.g., Black, 2012; Jafari, Taheri \& vom Lehn, 2013) also indicates that people may visit museums either individually or with different types of groups. The questionnaire was pilot tested with 75 respondents (who were not included in the actual survey) over a period of 21 days. Following the pilot test, some items were modified and some questions were restructured in order to clarify question wording. A final sample of 625 visitors was obtained in 2012. All completed questionnaires were included in the analysis. Table 3 presents the profiles of the participants.

Table 3: Gender, age, local or non-local, visiting group indicators of participants

\begin{tabular}{lcc}
\hline \multicolumn{1}{c}{ Socio-demographic indicators } & $\mathrm{n}$ & $\%$ \\
\hline Gender & & \\
Male & 355 & $53.8 \%$ \\
Female & 270 & $43.2 \%$ \\
Age & & \\
$18-25$ year old & 97 & $15.5 \%$ \\
$26-35$ year old & 175 & $28 \%$
\end{tabular}




\begin{tabular}{lcc}
$36-45$ year old & 221 & $35.4 \%$ \\
46-55 year old & 92 & $14.7 \%$ \\
56 years old or older & 40 & $6.4 \%$ \\
Local or non-local & & \\
Local & 318 & $50.9 \%$ \\
Non-local & 307 & $49.1 \%$ \\
Level of education & & \\
Basic qualifications & 168 & $26.9 \%$ \\
High school diploma & 153 & $24.5 \%$ \\
College certificates & 64 & $10.2 \%$ \\
University degree & 240 & $38.4 \%$ \\
Visiting group & & \\
Alone & 57 & $9.1 \%$ \\
With children & 91 & $14.6 \%$ \\
With friends & 309 & $49.4 \%$ \\
With family & 108 & $17.3 \%$ \\
With an organized tour & 60 & $9.6 \%$ \\
\hline
\end{tabular}

PLS was chosen as the method of analysis because it suits predictive applications and theory building (Chin, 2010), and is gaining popularity in tourism research (Alexander et al., 2012). It can be modeled in both formative and reflective modes (also see Chin, 2010; Hair et al. 2010). This was the main purpose of the study. Prior knowledge was measured as a formative construct. Such a construct consists of past experience, familiarity and expertise. The items comprising the measurement scale were developed from Kerstetter and Cho (2004). Past experience was assessed on the basis of number of previous visits (actual experience). As a self-reported measure, familiarity was assessed on the basis of degree of pre-visit information visitors (both first time and repeat) obtained from different sources. A single selfreported item ('I had good knowledge and expertise about the museum') measured expertise.

Cultural capital was operationalized with a view to Peterson's (2005) and Chan and Goldthorpe's (2007) notion of omnivore-univore. We investigated respondents' attending the same activities (i.e., classical music concert/opera, ballet/dance, theatre/life drama, museum/art gallery, pop music, movies, and reading literature). We employed a five point scale (ranging from "never" to "at least once a week") to measure the frequency of cultural taste. Level of education (varying from "no educational qualification" to "university degree") and variables measuring association with cultural occupation and background (e.g., if occupation was in any way related to culture) remain the same. We divided visitors into inactive (8-23) and active (24-42) based on the median (i.e., the middle score).The cultural capital index is an attribute that is theoretically formed from its components, and is therefore a 'formed attribute' (Rossiter, 2002).

Intrinsic motivation was measured as an eight-item reflective scale adapted from Gould, Moore, McGuire and Stebbin's (2008) study of motivation for serious leisure activities. The reason for this choice was that this was the main quantitative study of serious leisure motivation indicators. Principal Component Analysis (PCA) was performed on the importance rating of the 8 motivation factors identified in the instrument development process. The Cronbach's alpha value of .81 suggests internal reliability. No items had an inter item correlation of less than .5; therefore all items were retained. Oblique rotation was used to account for correlation between the factors (Hair et al., 2010). Based on mean scores, the 
PCA indicates two subscales of 'recreational' (enjoyment based enrichment) (5.32) and 'reflective' (self and identity projects) (4.70) motivations (Table 4).

Table 4 shows the lower mean for factor one (reflective motivation) compared with factor two (recreational motivation). This shows the importance of enjoyment for museum visitors. This aligns with Packer's (2006) assertion that a majority of museum visitors seek enjoyment and personal satisfaction. These two dimensions were consistent with the literature. Reflective motivation relates to individuals' self and identity projects (Falk et al., 2011; Goulding, 2000; Slater \& Armstrong, 2010) and recreational motivation is related to enjoyment based enrichment (Falk et al., 2012; Packer, 2006). As a result, $\mathbf{H}_{2}$ was amended to reflect the distinction between reflective and recreational motivations:

$\mathbf{H}_{2 \mathbf{a}}$ : Recreational motivation is positively related to level of engagement.

$\mathbf{H}_{2 \mathbf{b}}$ : Reflective motivation is positively related to level of engagement.

Table 4: Principal component analysis results for the motivation scale

\begin{tabular}{|c|c|c|c|c|c|c|c|}
\hline Item and description & Mean & S.D. & $\begin{array}{c}\text { Factor } \\
\text { loading }\end{array}$ & Communality & Eigenvalue & $\begin{array}{c}\% \\
\text { Variance }\end{array}$ & $\begin{array}{c}\text { Cronbach } \\
\text { alpha }\end{array}$ \\
\hline $\begin{array}{l}\text { Component 1: } \\
\text { Reflective Motivation }\end{array}$ & & & & & 3.712 & 46.397 & 0.720 \\
\hline $\begin{array}{l}4.3 \text { Visiting this } \\
\text { museum helps me to } \\
\text { express who I am } \\
\text { :Self-Express }\end{array}$ & 5.05 & 0.95 & & & & & \\
\hline $\begin{array}{l}4.2 \text { Visiting this } \\
\text { museum allows me to } \\
\text { display my knowledge } \\
\text { and expertise on } \\
\text { certain subjects: Self- } \\
\text { actualization }\end{array}$ & 4.97 & 1.05 & & & & & \\
\hline $\begin{array}{l}4.4 \text { Visiting this } \\
\text { museum has a positive } \\
\text { effect on how I feel } \\
\text { about myself-:Self- } \\
\text { image }\end{array}$ & & 0.91 & 0.835 & 0.643 & & & \\
\hline $\begin{array}{l}4.8 \text { Visiting this } \\
\text { museum allows me to } \\
\text { interact with others } \\
\text { who are interested in } \\
\text { the same things as me } \\
\text { : group attraction }\end{array}$ & 3.55 & 1.40 & 0.876 & 0.705 & & & \\
\hline $\begin{array}{l}\text { Component 2: } \\
\text { Recreational } \\
\text { Motivation }\end{array}$ & & & & & 2.225 & 15.306 & 0.745 \\
\hline $\begin{array}{l}4.6 \text { Visiting the } \\
\text { museum is a lot of } \\
\text { fun: Self-enjoyment }\end{array}$ & 5.61 & 1.00 & 0.745 & 0.567 & & & \\
\hline $\begin{array}{l}4.5 \text { I get a lot of } \\
\text { satisfaction from } \\
\text { visiting this museum: }\end{array}$ & 5.64 & 0.87 & 0.747 & 0.698 & & & \\
\hline
\end{tabular}


Satisfaction

\begin{tabular}{lllll}
$\begin{array}{l}\text { 4.7 I find visiting this } \\
\text { museum a refreshing } \\
\text { experience: Re- }\end{array}$ & 4.86 & 1.49 & 0.831 & 0.717 \\
creation & & & & \\
$\begin{array}{l}4.1 \text { Visiting this } \\
\text { museum is an }\end{array}$ & 5.19 & 1.00 & 0.676 & 0.555 \\
$\begin{array}{l}\text { enriching experience } \\
\text { for me: Personal } \\
\text { enrichment }\end{array}$ & & & & \\
\hline
\end{tabular}

$\mathrm{KMO}=.790 ;$ Bartlett's test $p<.000$.

\section{Research results}

In the case of the reflective scales (i.e., reflective and recreational motivations) (Table 5), Cronbach's alpha indicates more than .7 for both scales. Composite reliability $\left(\rho_{c r}\right)$ scores range from .73 to .74 above the recommended cut off of .7 (Hair et al., 2010). Convergent validity was assessed using average variance extracted (AVE) and our factors scored .60 and .57 once again meeting the .5 threshold suggested (Chin, 2011; Hair et al., 2010). Finally, discriminant validity of the scales was measured by comparing the square root of AVE (represented the diagonal with inter-construct correlations in Table 6). All appear to support the reliability and validity of the reflective scales.

Following Diamantopoulos and Winklhofer's (2001) four-step procedure for formative scales, we checked the multicollinearity among the indicators. The Variance Inflation Factor (VIF) was used to assess multicollinearity (Table 4). We performed a collinearity test on engagement and prior knowledge indicators. The results show minimal collinearity among the indicators, with VIF of all items ranging between 1.37 and 2.50, below the common cut off of 5 . As a result, the assumption of multicollinearity is not violated (Chin, 2010).

For the external validation, we examined whether each indicator could be significantly correlated with a 'global item' that summarizes the spirit of prior knowledge and engagement scales. Therefore, we developed two additional statements: 'I felt that my prior knowledge helped in my visit to this museum' and 'I have engaged with the museum in my visit'. As shown in Table 7, all indicators significantly correlated with these two statements; consequently, all indicators were included in our study (see also Wiedmann et al., 2011). After following the systematic four-step approach, our proposed engagement and prior knowledge constructs can be regarded as valid formative measurement instruments.

Table 5: Assessment of the measurement model

\begin{tabular}{lclll}
\hline Path & Mean (SD) & $\begin{array}{l}\text { Weights/ } \\
\text { loadings }\end{array}$ & Scales & VIF/Reliability \\
Past experience $\rightarrow$ PK & $4.10(1.62)$ & $0.750^{* *}$ & $\begin{array}{l}\text { Prior } \\
\text { Knowledge } \\
\text { (Formative) }\end{array}$ & 2.32 \\
Familiarity $\rightarrow$ PK & $3.53(1.66)$ & $-0.154^{* *}$ & & 2.33 \\
$\begin{array}{l}\text { Expertise } \rightarrow \text { PK } \\
\text { MOT } \rightarrow \text { Personal }\end{array}$ & $4.17(1.48)$ & $0.300^{*}$ & & 2.00 \\
enrichment & $5.19(1.00)$ & $0.700^{* *}$ & $\begin{array}{l}\text { Recreational } \\
\text { Motivation } \\
\text { (Reflective) }\end{array}$ & $\begin{array}{l}\text { AVE }=0.79, \\
\rho_{c r}=0.74\end{array}$ \\
MOT $\rightarrow$ satisfaction & $5.64(0.87)$ & $0.764^{* *}$ & &
\end{tabular}




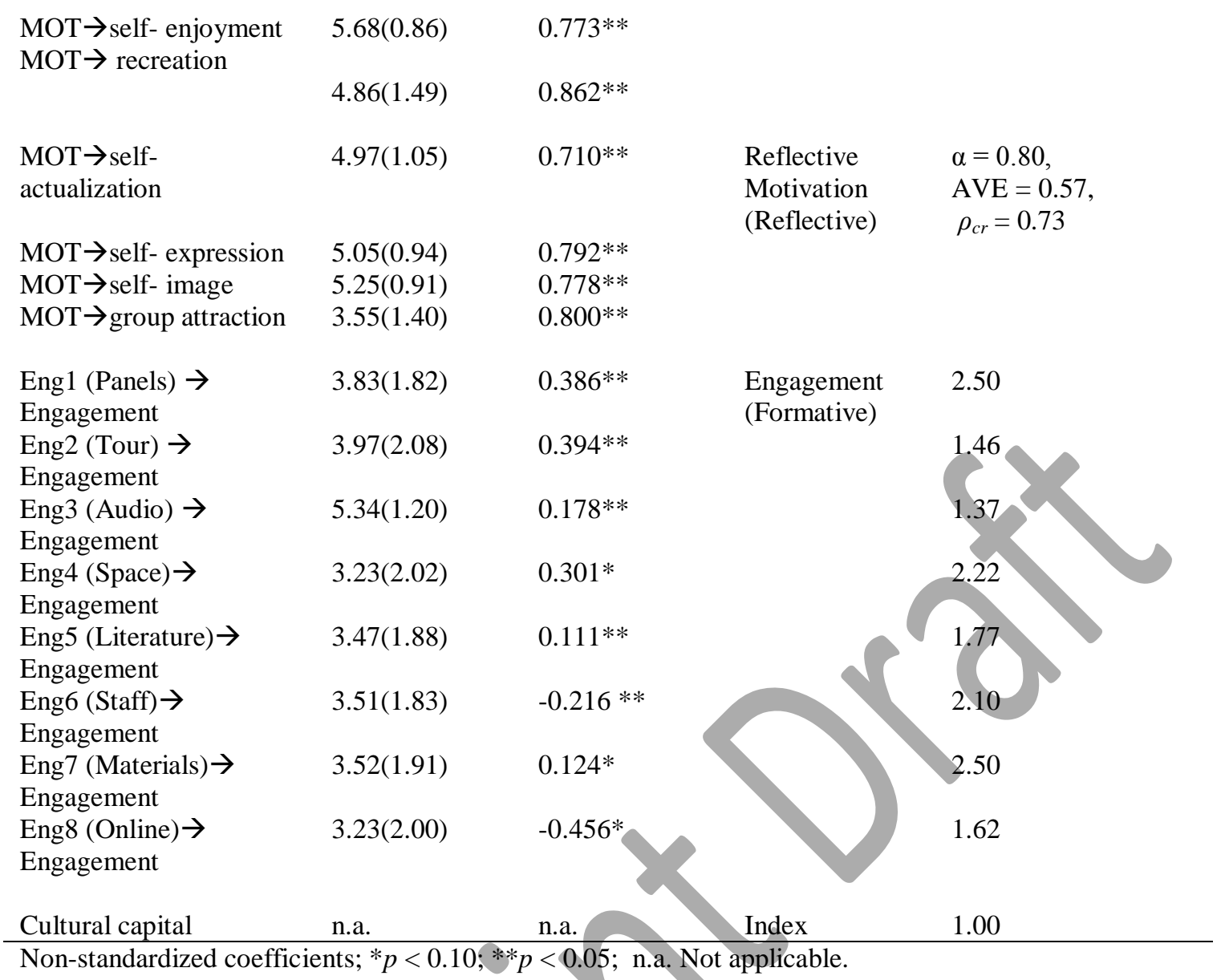

Table 6: Latent variables correlation matrix (reflective measures)

\begin{tabular}{|c|c|c|c|c|c|}
\hline 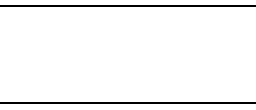 & $\begin{array}{l}\text { Cultural } \\
\text { capital }\end{array}$ & Engagement & $\begin{array}{l}\text { Reflective } \\
\text { motivation }\end{array}$ & $\begin{array}{l}\text { Prior } \\
\text { knowledge }\end{array}$ & $\begin{array}{l}\text { Recreational } \\
\text { motivation }\end{array}$ \\
\hline $\begin{array}{l}\text { Cultural } \\
\text { capital }\end{array}$ & & & & & \\
\hline Engagement & -0.16 & n.a. & & & \\
\hline $\begin{array}{l}\text { Reflective } \\
\text { motivation }\end{array}$ & & -0.51 & 0.77 & & \\
\hline $\begin{array}{l}\text { Prior } \\
\text { knowledge }\end{array}$ & 0.08 & -0.45 & 0.41 & n.a. & \\
\hline $\begin{array}{l}\text { Recreational } \\
\text { motivation }\end{array}$ & -0.43 & 0.39 & -0.44 & -0.51 & 0.75 \\
\hline
\end{tabular}

Table 7: Test for external validity of formative measures

\begin{tabular}{ll}
\hline Items & $\begin{array}{l}\text { Spearman's rank } \\
\text { correlation coefficient }\end{array}$ \\
\hline
\end{tabular}

\begin{tabular}{ll}
\hline Prior Knowledge & \\
Familiarity & $.546^{*}$ \\
Expertise & $.509^{*}$ \\
Past Experience & $.639^{*}$
\end{tabular}




\begin{tabular}{ll} 
Engagement & \\
Eng 1 & $.312^{*}$ \\
Eng 2 & $.276^{*}$ \\
Eng 3 & $.868^{*}$ \\
Eng 4 & $.336^{*}$ \\
Eng 5 & $.650^{*}$ \\
Eng 6 & $.650^{*}$ \\
Eng 7 & $.336^{*}$ \\
Eng 8 & $.357^{*}$ \\
\hline
\end{tabular}

$* p<0.05 ;$ N.B. (2-tailed).

To examine the hypotheses, the structural model was tested within SmartPLS (Ringle, Wende, \& Becker, 2005) and 500 sub-samples were randomly generated. All hypothesized relationships in our conceptual model are supported except the influence of reflective motivation on level of engagement $\left(\mathbf{H}_{\mathbf{2 b}}\right)$ (Table 8). Regarding effect size, the model has good predictive power, with an $\mathrm{R}^{2}$ of .59 , denoting $59 \%$ of the variance in engagement explained by the independent variables based on Chin's (2010) study. Chin (2010, p.665) argues that the formative model should have a higher $\mathrm{R}^{2}$ because "PLS based formative indicators are inwards directed to maximize the structural portion of the model". However, when we tested the models while considering the engagement construct as reflective, the value of $\mathrm{R}^{2}$ was not as high as the one originated by the formative model (i.e., $\mathrm{R}^{2}=.27$ ). Therefore, the formative measure is a better choice for this study. The model's predictive validity was analyzed using Stone-Geisser test criterion $Q^{2}$ (Chin. 2010). If $Q^{2}>0$, the model has predictive relevance. $Q^{2}$ is .341 for engagement, .574 for reflective motivation, .593 for recreational motivation, and .570 for prior knowledge; all scales have predictive relevance.

Table 8: The results of hypothesis testing

\begin{tabular}{lcl}
\hline Path & $\begin{array}{c}\text { Standardized } \\
\text { path coefficients }\end{array}$ & Result \\
\hline $\mathrm{H}_{1}:$ Prior Knowledge $\rightarrow$ Engagement & $+0.61^{*}$ & Supported \\
$\mathrm{H}_{2 \mathrm{a}}:$ Recreational motivation $\rightarrow$ Engagement & $+0.21^{*}$ & Supported \\
$\mathrm{H}_{2 \mathrm{~b}}:$ Reflective motivation $\rightarrow$ Engagement & +0.08 & Rejected \\
$\mathrm{H}_{3}:$ Cultural Capital $\rightarrow$ Engagement & $+0.18^{*}$ & Supported \\
\hline
\end{tabular}
$* p<0.05$.

\section{Conclusion and implications}

This study responded to the need of a scale to measure visitors' level of engagement in tourism studies (Black, 2005; Falk et al., 2011). Initially, we developed and tested an engagement measurement scale with an aggregate of 8 items. As an important tool, this scale can complement the existing research methods in better understanding of visitors' engagement. This method particularly reduces ambiguities around what constitutes engagement. Our research also contributes to theory development by establishing how level of engagement can be modeled as a formative construct and influenced by (mixture of formative and reflective) drivers of engagement incorporated in a structural model.

We documented the strong predictive influence of prior knowledge on level of engagement (Table 8). This aligns with previous studies on that prior knowledge influences individuals' cultural consumption experience in general (Caru \& Cova, 2005) and their level 
of engagement with(in) museums in particular (Falk \& Storksdieck, 2005). We also provided solid empirical evidence for previous calls (Black, 2005; Ho, Lin, \& Chen, 2012) for investigating the relationship between visitors' prior knowledge and their level of engagement. Our study advances measurement of prior knowledge within the area of tourist behavior. Furthermore, we critiqued previous studies for their dispersed conceptualization of prior knowledge and addressed Kerstetter and Cho's (2004) call for adopting 'aggregated' (formative) measure to analyze the concept. We argued that dropping any dimension(s) of prior knowledge alters the conceptual meaning of the construct. Such an approach acknowledges commitment to conceptual meanings and advocates holistic analyses. Additionally, we tested cultural capital from Peterson's (2005) and Chan and Goldthorpe's (2007) 'omnivore-univore' perspectives. A positive significant link was found between the cultural capital index and level of engagement (Table 8). This is a valuable finding which sheds light on conceptualizing the nature of cultural capital as extensively used by researchers in the field of tourism. The 'omnivore-univore' approach provides a theoretical explanation for the way people behave in contemporary society. This implies that the 'frequency' (Peterson, 2005) of people's participation in cultural consumption is a highly significant factor which should not be overlooked. Furthermore, the study provides strong empirical evidence for the role of 'accumulated' cultural capital in the visitor agenda and cultural experience which was indicated by Falk et al. (2011). This means that it is not only the prior knowledge of the museum in question which influences visitors' level of engagement but also their accumulated cultural capital.

We explored the link between intrinsic motivations and engagement, differentiating between 'reflective' and 'recreational' motivations (Table 8). Whilst there was a significantly positive link between the latter and the level of engagement, surprisingly, the former did not have any significant influence. Given the emphasis of prior research (e.g., Black, 2005; Sheng $\&$ Chen, 2012) on the impact of reflective motivation on the level of engagement, such a result is valuable. Also, unlike previous studies (e.g., Prentice, 2001; Falk and Storksdieck, 2010; Brodie et al., 2011; Falk et al., 2011), our findings demonstrate that the 'self and identity project' motivation does not influence the level of involvement with and commitment to a consumption experience. We suspect that the results could probably differ in specificallythemed tourism attractions (e.g., war museums) where visitors would perhaps encounter more profound experiences such as self and identity projects. Regarding the relationship between recreational motivation and engagement, our study reveals results similar to those of previous studies. That is, as visitors pursue temporary moments of 'recreation' (Black, 2005; Slater, 2007; Slater \& Armstrong, 2010) and 'enjoyment' (Packer, 2006; Falk et al., 2012), their level of engagement significantly increases.

Based on these premises, a series of managerial implications emerge. Tourism attractions should endeavor to constantly assess their success in relation to their visitors' repeat visits. As we discussed earlier in this paper, people's interest in a given attraction lies in their satisfactory experience with(in) an attraction. Such an experience, on the other hand, is the outcome of visitors' engagement with the attraction context and contents. Therefore, tourism managers need to use the aggregated visitor engagement assessment as a tool to optimize their own performance. Our proposed engagement scale provides such a valuable tool by means of which managers can assess visitors' level of engagement more systematically. We should emphasize that we do not propose this tool to replace, but to complement, other research methods such as observations and experiments. 
Table 5 highlights all items are determinants of engagement and statistically significant. Therefore, managers could use this holistic scale to measure visitors' engagement. Of all items, using 'interactive panels' and 'guided tour' have the strongest influence on engagement, followed by using 'social interaction space' and 'videos and audios'. This means that involvement with specific objects (e.g., 'using interactive panels') and commitment to service offerings (e.g., using 'social interaction space' and 'guided tour') play an important role (Brodie et al., 2011; Higgins \& Scholer, 2009). Seeking help from staff and using the onsite online facilities have negatively influenced the visitors' engagement. Our interpretation is that either staff members were not available on site or visitors were not interested in interacting with them. In terms of the latter, our study did not identify any particular reason. We recommend that managers investigate these two items in their own settings. Appendix 1 offers a set of instructions for managers to interpret the results of our engagement scale.

Additionally, as the tool establishes a link between the 'drivers' and 'level' of engagement, managers could use it as a diagnostic instrument to identify the predictive power of each driver of engagement and its impact on visitors' engagement. They can ascertain which driver(s) predominantly influence(s) level of engagement more and then focus their efforts on improving their service. Such efforts would confidently contribute to awareness about the attraction and repeat visits. This means that managers can adopt suitable strategies to address issues related to drivers of engagement. For example, virtual tours on museum websites may be regarded as a useful means of familiarizing potential audiences with the attraction. The British Museum's use of a series of radio programs (in collaboration with the BBC), accompanied by online podcasts and photographs, may be seen as an exemplar of such a strategy. These complementary tools can enrich audiences' overall knowledge of the attraction whereby they can draw broader meanings from objects and actively seek them out during their visits. Application of such methods, however, needs to be carefully justified upon further research and in accordance with the nature of the attractions.

Barr (2005) asserted that over-explanation of the museum contents may result in the 'dumbing down' of the audience's intellectual capacity. This means that creating a balanced approach to the generation and dissemination of knowledge about the museum is a prime challenge for museum managers. Given the multi-dimensionality of prior knowledge, tourist behavior research should acknowledge the importance of adopting a 'holistic' approach to analyzing the relationship between consumers' accumulated prior knowledge and their engagement with and appreciation of the object of consumption. For example, in the case of destination (e.g., Baloglu, 2001; Prentice, 2004a), increasing potential tourists' prior knowledge can alter their perception, experience, and engagement with target attractions/destinations. Likewise, in the context of museums, managers should endeavor to leverage visitors' prior knowledge in order to optimize cultural consumers' engagement with the museum offerings. Finally, in the prior knowledge scale, the 'past experience' item has scored very high indicating that mangers should focus their strategies on repeat visits.

Given the importance of recreational motivation benefits, tourism managers should promote more dynamic activities such as themed interactive exhibitions. For example, managers could organize reminiscence and engagement sessions using their artifacts and other art forms to generate conversation, and encourage visitors to provide them with feedback on improving both enjoyment and long term engagement with their offerings. This may question the usefulness of traditional dichotomous categorization of people into 'mindful and mindless' visitors (Moscardo, 1996) to the advancement of knowledge in cultural tourism. As such, museums - which traditionally have been viewed mainly as serious leisure 
contexts that offer extrinsic rewards (see also Stebbins, 2009) - have great potential in contributing to people's sense of enjoyment.

Earlier we discussed that omnivore individuals (Peterson, 2005; Tampubolon, 2010) frequently consume different cultural experiences. However, omnivore audiences are not homogeneous; compared to inactive individuals, active ones engage more with service offerings (e.g., heritage sites). Understanding the differences between these can offer important implications for achieving long-terms success for cultural sites such as museums. Managers can use our proposed scale to better understand the relationship between visitors' cultural capital and their engagement level. Since active visitors seek more engaging moments in the sites they visit, managers should endeavor to enhance the quality, quantity, and diversity of their engagement facilities.

Just like any other piece of research, this study is not limitation-proof. Although large in scale, our choice of Kelvingrove as a general museum limits the generalizability of our proposed model to other tourist attractions. Therefore, we would like to invite our colleagues to apply the model and engagement scale to other research settings, for example, heritage sites and theme parks. Our study sought to develop a scale where none existed. Therefore, this scale opens new paths for further empirical work. Furthermore, although we used exploratory interviews to develop the scale, our study was mainly quantitative in nature. Hence, we suggest that a holistic understanding of the concept of engagement would require a longitudinal study using multimodal research design (including qualitative and quantitative methods). Also, future research should investigate the concept of engagement and its drivers in different types of socio-cultural contexts as behavior is shaped by multiple socio-cultural, economic, and political factors. Last but not least, for ethical considerations, we did not study respondents under eighteen years of age. It would be interesting to understand whether or not participants under this age would show a different level of engagement.

\section{Acknowledgement}

The authors would like to thank and acknowledge Mark McMahon Graphic Designs (m_mcmahon1988@hotmail.co.uk) for his help in drawing the graphical abstract. 


\section{References}

Abdul-Ghani, E., Hyde, K. F., \& Marshall, R. (2011). Emic and etic interpretations of engagement with a consumer-to-consumer online auction site. Journal of Business Research, 64(10), 1060-1066.

Alexander, M., MacLaren, A., O’Gorman, K., \& Taheri, B. (2012). "He just didn't seem to understand the banter": Bullying or simply establishing social cohesion? Tourism Management, 33(5), 1245-1255.

Ballantyne, R., Packer, J., \& Falk, J. (2011). Visitors' learning for environmental : Testing short- and long-term impacts of wildlife tourism experiences using structural equation modelling. Tourism Management, $32(6), 1243-1252$.

Ball, A. D. \& L. H. Tasaki (1992). The Role and Measurement of Attachment in Consumer Behavior, Journal of Consumer Psychology, 1(2),155-72.

Baloglu, S. (2001). Image variations of Turkey by familiarity index: Informational and experiential dimensions. Tourism Management, 22, 127-133.

Baloglu, S., \& Uysal, M. (1996). Market segments of push and pull motivations: A canonical correlation approach. International Journal of Contemporary Hospitality Management, 8(3), 32-38.

Barbieri, C., \& Sotomayor, S. (2013). Surf travel behavior and destination preferences: An application of the Serious Leisure Inventory and Measure. Tourism Management, 35(0), 111-121.

Barr, J. (2005). Dumbing down intellectual culture: Frank Furedi, lifelong learning and museums. Museum and Society, 3(2), 98-114.

Black, G. (2005). The engaging museum: Developing museums for visitor involvement. London: Routledge.

Black,G. (2012). Transforming museums in the $21^{\text {st }}$ Century. London: Routledge.

Bourdieu, P. (1984). Distinction: A social critique of the judgment of taste (R. Nice, Trans.). Cambridge, MA: Harvard University Press.

Boyatzis, R. E. (1998). Transforming qualitative information: Thematic analysis and code development. London: Sage.

Brodie, R. J., Hollebeek, L. D., Juric', B., \& Ilic', A. (2011). Customer engagement: Conceptual domain, fundamental propositions, and implications for research. Journal of Service Research, 14(3), 252-271.

Brodie, R. J., Ilic, A., Juric, B., \& Hollebeek, L. (2013). Consumer engagement in a virtual brand community: An exploratory analysis. Journal of Business Research, 66(1), 105-114

Caru, A., \& Cova, B. (2005). The impact of service elements on the artistic experience: The case of classical music concerts. International Journal of Arts Management, 7(2), 39-54.

Chan, T. W., \& Goldthorpe, J. H. (2007). Social stratification and cultural consumption: The visual arts in England. Poetics, 35, 168-190.

Chin, W. W. (2010). How to write up and report PLS analyses. In V. Esposito Vinzi, W. W. Chin, J. Henseler \& H. Wang (Eds.), Handbook of Partial Least Squares: Concepts, Methods and Applications (pp. 655690). Berlin: Springer.

Diamantopoulos, A., \& Winklhofer, H. M. (2001). Index construction with formative indicators: An alternative to scale development. Journal of Marketing Research, 38(2), 269-277.

Edmonds, E., Muller, L., \& Connell, M. (2006). On creative engagement. Visual Communication, 5(3), $307-322$.

Falk, J. H, \& Storksdieck, M. (2005). Using the contextual model of learning to understand visitor learning from a science center sxhibition. Science Education, 89, 744-778.

Falk, J. H., \& Dierking, L. D. (1992). The museum experience. Washington D.C.: Whalesback.

Falk, J. H., Dierking, L. D., \& Adams, M. (2011). Living in a learning society: Museums and free-choice learning In S. Macdonald (Ed.), A companion to museum studies (pp. 323-339). UK: Blackwell.

Falk, J. H., \& Storksdieck, M. (2010). Science learning in a leisure setting. Journal of Research in Science Teaching, 47(2), 194-212.

Falk, J. H., Ballantyne, R., Packer, J., \& Benckendorff, P. (2012). Travel and learning: A neglected tourism research area. Annals of Tourism Research, 39(2), 908-927.

French, V., \& Runyard, S. (2011). Marketing and public relations for museums, galleries, cultural and heritage attractions. London: Routledge.

Gould, J., Moore, D., McGuire, F., \& Stebbins, R. (2008). Development of the Serious Leisure Inventory and measure. Journal of Leisure Research, 40(1), 47-68.

Goulding, C. (2000). The museum environment and the visitor experience. European Journal of Marketing, 34(3/4), 261-278.

Gursoy, G., \& McCleary, K. W. (2004). An integrative model of tourist's information search behavior. Annals of Tourism Research, 31(2), 353-373.

Hair, J. F. J., Black, W. C., Babin, B. J., \& Anderson, R. E. (2010). Multivariate data analysis: A global perspective (7 ed.). USA: Pearson.

Higgins, T., E. , \& Scholer, A. A. (2009). Engaging the consumer: The science and art of the value creation process. Journal of Consumer Psychology, 19(2), 100-114. 
Ho, C.I., Lin, M.H., \& Chen, H.-M. (2012). Web users' behavioural patterns of tourism information search: From online to offline. Tourism Management, 33(6), 1468-1482.

Hollebeek, L. D. (2010). Demystifying customer brand engagement: Exploring the loyalty nexus. Journal of Marketing Management, 27 (7-8), 785-807

Holt, D. B. (1998). Does cultural capital structure American consumption?. Journal of Consumer Research, $25(1), 1-25$.

Iso-Ahola, S. E. (1982). Toward a social psychological theory of tourism motivation: A rejoinder. Annals of Tourism Research, 9(2), 256-262.

Jafari, A., Taheri, B., \& vom Lehn, D. (2013). Cultural consumption, interactive sociality, and the museum. Journal of Marketing Management, iFirst.

Kerstetter, D., \& Cho, M.-H. (2004). Prior knowledge, credibility and information search. Annals of Tourism Research, 31(4), 961-985.

Kim, H., Cheng, C.K., \& O'Leary, J. T. (2007). Understanding participation patterns and trends in tourism cultural attractions. Tourism Management, 28(5), 1366-1371.

Kolar, T., \& Zabkar, V. (2010). A consumer-based model of authenticity: An oxymoron or the foundation of cultural heritage marketing? Tourism Management, 31(5), 652-664.

Marci, C. D. (2006). A biologically based measure of emotional engagement: Context matters. Journal of Advertising Research, 46(4), 381-387.

Mitchell, A., \& Dacin, P. (1996). The assessment of alternative measures of consumer expertise. Journal of Consumer Research, 23, 219-239.

Mollen, A., \& Wilson, H. (2010). Engagement, telepresence and interactivity in online consumer experience: Reconciling scholastic and managerial perspectives. Journal of Business Research, 63(9-10), 919-925.

Moore, W., \& Lehmann, D. (1980). Individual differences in search behavior for a nondurable. Journal of Consumer Research, 7, 296-307.

Morris Hargreaves McIntyre. (2009). Part of my city, part of my heritage: Visitor research at Kelvingrove Art Gallery and Museum report. Kelvingrove Art Gallery and Museum Archive.

Moscardo, G. (1996). Mindful visitors, heritage and tourism. Annals of Tourism Research, 23, 376-397.

Packer, J. (2006). Learning for fun: The unique contribution of educational leisure experiences. Curator, 49(3), 320-344.

Park, C. W., \& Lessig, V. P. (1981). Familiarity and its impact on consumer decision biases and heuristics. Journal of Consumer Research, 8(2), 223-231.

Park, D.-B., \& Yoon, Y.-S. (2009). Segmentation by motivation in rural tourism: A Korean case study. Tourism Management, 30(1), 99-108.

Pattakos, A. (2010). Discovering the deeper meaning of tourism. In R. Wurzburger, T. Aageson, A. Pattakos \& S. Pratt (Eds.), Discovering the deeper meaning of tourism creative tourism: A global conversation (pp. 53-62): Santa Fe, Sunstone Press.

Peterson, R. A. (2005). Problems in comparative research: The example of omnivorousness. Poetics, 33(5-6), 257-282.

Pimentel, R. W. \& Kristy E. Reynolds (2004), A Model for consumer devotion: Affective commitment with proactive sustaining behaviors, Academy of Marketing Science Review, 5, 1-45.

Prentice, R. (2001). Experiential cultural tourism: Museums \& the marketing of the new romanticism of evoked authenticity. Museum Management and Curatorship, 19(1), 5-26.

Prentice, R. (2004a). Tourist familiarity and imagery. Annals of Tourism Research, 31(4), 923-945.

Prentice, R. (2004b). Tourist motivation and typologies. In A. A. Lew, M. C. Hall \& M. A. Williams (Eds.), A companion to tourism (pp. 498-509). Oxford: Blackwell Publishing.

Ringle, C. M., Wende, S., \& Becker, J.-M. (2005). SmartPLS 2.0. Retrieved October 18, 2009, from SmartPLS Web Site: http://www.smartpls.de/forum/

Rossiter, J. R. (2002). The C-OAR-SE procedure for scale development in marketing. International Journal of Research in Marketing, 19(4), 305-335.

Serrell, B. (1998). Paying attention: Visitors and museum exhibitions. Washington, DC: American Association of Museums.

Sheng, C.-W., \& Chen, M.-C. (2012). A study of experience expectations of museum visitors. Tourism Management, 33, 53-60.

Siu, N. Y.-M., Zhang, T. J.-F., Dong, P., \& Kwan, H.-Y. (2013). New service bonds and customer value in customer relationship management: The case of museum visitors. Tourism Management, 36, 293-303.

Slater, A. (2007). Escaping to the gallery: Understanding the motivations of visitors to galleries. International Journal of Nonprofit and Voluntary Sector Marketing, 12, 149-162.

Slater, A., \& Armstrong, K. (2010). Involvement, tate, and me. Journal of Marketing Management, 26(7), $727-$ 748.

Stebbins, R. (2009). Leisure and consumption: Common ground/separate worlds. UK: Palgrave. 
Stringfellowb,L., Maclaren, A., Maclean, M., \& O’Gorman, K.(2013). Conceptualizing taste: Food, culture and celebrities. Tourism Management, 37, 77-85.

Tampubolon, G. (2010). Social stratification and cultures hierarchy among the omnivores: Evidence from the Arts Council England surveys. The Sociological Review, 58(1), 1-25.

van Doorn, J., Lemon, K.N., Mittal, V., Nass, S., Pick, D., Pirner, P., \& Verhoef, P.C., (2010). Customer engagement behavior: Theoretical foundations and research directions. Journal of Service Research, 13, 253-266.

Wang, A. (2006). Advertising engagement: A driver of message involvement on message effects. Journal of Advanced Research, 46(4), 355-368.

Welsh, P. H. (2005). Re-configuring museums. Museum Management and Curatorship, 20, 103-130.

Wiedmann, K.-S., Hennigs, H., Schmidt, S., \& Wuestefeld, T. (2011). Drivers and outcomes of brand heritage: Consumers' perception of heritage brands in the automotive industry. Journal of Marketing Theory and Practice, 19(2), 205-220.

Žabkar, V., Brenčič, M. M., \& Dmitrovič, T. (2010). Modelling perceived quality, visitor satisfaction and behavioural intentions at the destination level. Tourism Management, 31, 537-546. 
Appendix 1: Interpretation sheet for managers

\begin{tabular}{|c|c|c|c|}
\hline \multirow{4}{*}{ 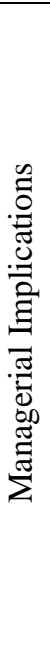 } & \multicolumn{3}{|c|}{ Engagement Score } \\
\hline & $\begin{array}{l}\text { Low }(\mathbf{0 - 2}) \\
\text { Your visitors do not sufficiently engage } \\
\text { with the site }\end{array}$ & $\begin{array}{l}\text { Middle (2-4) } \\
\text { Your visitors demonstrate an intermediate level of } \\
\text { engagement with the site; however, there is room to } \\
\text { enhance their engagement }\end{array}$ & $\begin{array}{l}\text { High ( } 4 \text { and more) } \\
\text { Your visitors demonstrate a high level of engagement } \\
\text { with the site }\end{array}$ \\
\hline & $\begin{array}{l}\text { - Undertake research to find out the } \\
\text { reason(s) why this exists }\end{array}$ & - Identify the areas that could b & - Maintain your current strategy \\
\hline & \multicolumn{2}{|c|}{$\begin{array}{l}\text { - Review your existing marketing strategy } \\
\text { - Identify the gap(s) between visitors' perception of the site and that of yours } \\
\text { - Direct your overall strategic marketing and management activities toward improving visitors' } \\
\text { engagement as a prime objective } \\
\text { - Devise suitable engagement activities such as enhancing visitors' knowledge, providing more } \\
\text { enjoyable environments, increasing the diversity of service offerings }\end{array}$} & $\begin{array}{l}\text { - Undertake periodic research to identify new offerings } \\
\text { - Search for new ways of enhancing visitors' level of } \\
\text { engagement } \\
\text { - Constantly monitor your activities to ensure the } \\
\text { sustenance of visitors' engagement }\end{array}$ \\
\hline
\end{tabular}

